\title{
Heat Killed Attenuated Leishmania Induces Apoptosis of HepG2 Cells Through ROS Mediated p53 Dependent Mitochondrial Pathway
}

\author{
Dipayan Bose Somenath Banerjee Subhadip Das Nabanita Chatterjee \\ Krishna Das Saha \\ Cancer Biology and Inflammatory Disorder Division, CSIR-Indian Institute of Chemical Biology, Kolkata, \\ India
}

\section{Key Words}

Leishmania donovani $\bullet \mathrm{UR6} \cdot \mathrm{HepG} \cdot \mathrm{p} 53 \cdot \mathrm{ROS} \cdot \mathrm{Gp} 91$

\begin{abstract}
Background/Aims: Cytotoxic effect of attenuated Leishmania on liver cancer cells by inducing ROS generation. Methods: Spectrophotometric study to analyze cell death and levels of different active caspases. Flow cytometric study was done to analyze apoptosis induction and ROS generation and levels of different protein. Western blot analysis was performed to study the levels of protein. Confocal microscopy was done to ascertain the expression of different apoptotic markers. Results: We have now observed that attenuated Leishmania donovani UR6 also has potentiality towards growth inhibition of HepG2 cells and investigated the mechanism of action. The effect is associated with increased DNA fragmentation, rise in number of annexinV positive cells, and cell cycle arrest at G1 phase. The detection of unregulated levels of active PARP, cleaved caspases 3 and 9, cytosolic cytochrome C, Bax, and Bad, along with the observed downregulation of $\mathrm{Bcl}-2$ and loss of mitochondrial membrane potential suggested the involvement of mitochondrial pathway. Enhanced ROS and p53 levels regulate the apoptosis of HepG2 cells. NAC was found to inhibit p53 production but PFT- $\alpha$ has no effect on ROS generation. In conclusion, Leishmania donovani UR6 efficiently induces apoptosis in HepG2 cells through ROS mediated p53 dependent mitochondrial pathway. Conclusion: It has been reported earlier that some parasites show prominent cytotoxic effect and prevent tumor growth. From our study we found that Leishmania donovani UR6 efficiently induced apoptosis in HepG2 cells through ROS mediated p53 dependent mitochondrial pathway. This study has rejuvenated the age old idea of bio-therapy.




\section{Cellular Physiology Cell Physiol Biochem 2016;38:1303-1318

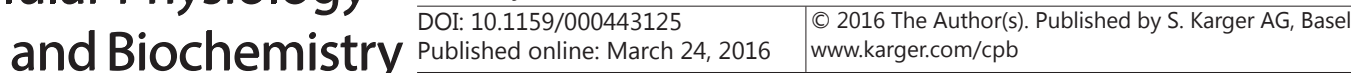 \\ Bose et al.: Attenuated Leishmania Induces Apoptosis of HepG2 Cells}

\section{Introduction}

Cancer, which was most prominent in economically developing countries earlier, is now the second most common cause of death in developing countries [1]. It is characterized by uncontrolled and invasive growth patterns. Failures in therapies and relapse are leading causes of death due to cancer. Liver cancer is the fifth most frequently diagnosed cancer in men and the second most frequent cause of cancer death, while in women it is the seventh most common cancer and sixth leading cause of death due to cancer [1]. Conventional anticancer therapies like surgical resection, chemotherapy and radio therapy are not satisfactory for several types of cancer and alternative strategies are being adopted to treat cancers that are resistant to therapies in use.

Nauts et al. in 1953 first showed that microbes can elicit antitumor response in host [2]. Long after this work, natural attenuated and genetically modified organisms that are non-pathogenic were explored as antitumor agents acting either by exerting tumoricidal activity or via delivering tumoricidal molecules. They also cause tissue tropism by growing selectively in tumor cells and inhibiting their growth or destroying them. But the antagonism between the protozoan Trypanosoma cruzi (causative agent of Chagas disease) and tumor growth was first discovered as early as 1931 [3]. Subsequently, Toxoplasma gondii and Acanthamoeba castellanii were also reported to have antitumor activity [4-9]. This gave birth to the new branch of oncology, viz. "Biotherapy", the term which was first introduced by Roskin and co-workers [3].

We initiated this work to elucidate the cytotoxic property of an attenuated strain of the protozoa Leishmania donovani UR6 against liver carcinoma cell line HepG2. The work was focused on the effect of heat killed attenuated L. donovani UR6 strain on the growth and death of HepG2 cells. There are reports that heat killed L. donovani UR6 shows immune stimulation with the generation of ROS in peritoneal macrophages [10]. Excessive ROS production is known to be associated with induction of apoptosis in cancer cells [11-13]. So we became interested to see whether UR6 can also generate ROS in HepG2 cells. ROS is reported to induce activation of p53 protein [14, 15], a tumor suppressor factor, and its excessive production is associated with induction of apoptosis in cancer cells. It was therefore of interest to find out if UR6 also can generate enough ROS in HepG2 cells to induce apoptosis and the mechanism involved therein. We were however aware of the report that another species of the genus Leishmania, viz. Leishmania major, exhibits no tumoricidal property [16].

\section{Materials and Methods}

\section{Reagents}

Dulbecco's modified Eagle medium (DMEM), fetal bovine serum (FBS), penicillin-streptomycinneomycin (PSN) antibiotic, trypsin and ethylenediaminetetraaceticacid (EDTA) were obtained from Gibco BRL (Grand Island, NY, USA). Tissue culture plastic wares were procured from NUNC (Roskilde, Denmark). Antibodies were purchased from Santa Cruz Biotechnology, Inc USA and eBioscience Inc., San Diego, USA. Organic solvents used were of HPLC grade. All other chemicals including doxorubicin used were from Sigma Chemical Co. (St. Louis, MO, USA) or mentioned otherwise.

\section{Cell Culture}

Cell lines were purchased from National Centre for Cell Science, Pune, India. HCT116 p53\% was a kind gift from Dr. Bert Vogelstein of Johns Hopkins University, Baltimore, MD. All the cells were cultured in either DMEM or RPMI1640 containing 10\% FBS and antibiotics $(100 \mathrm{U} / \mathrm{ml}$ of Penicillin, $100 \mu \mathrm{g} / \mathrm{ml}$ of Streptomycin). Cells were maintained in appropriate environment with $5 \% \mathrm{CO}_{2}$ at $37^{\circ} \mathrm{C}$. When $75-80 \%$ confluency was reached cells were harvested using $0.025 \%$ trypsin and $0.52 \mathrm{mM}$ EDTA in PBS. All the experiments were performed with appropriate medium. 


\section{Cellular Physiology Cell Physiol Biochem 2016;38:1303-1318

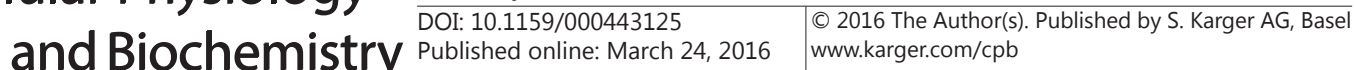 \\ Bose et al.: Attenuated Leishmania Induces Apoptosis of HepG2 Cells}

Culture of Leishmania donovani

Attenuated Leishmania strain (MHOM/IN/1978/UR6), originally isolated from an Indian Kala-azar patient and grown and maintained in modified Ray's medium since long in Indian Institute of Chemical Biology, was subcultured at $72 \mathrm{~h}$ intervals [17] and stored in PBS at $-20^{\circ} \mathrm{C}$ for overnight. The cells were counted by haemocytometer and were heat killed at $80^{\circ} \mathrm{C}$ and sonicated for 3 mins at $12 \mathrm{kHz}$ by probe sonicator Q125, QSonics. Heat killed attenuated Leishmania donovani cells were added to mammalian cell culture in quantities to make final concentration of cells as per requirement.

\section{Cell viability assay}

Cell viability was assayed by MTT [3-(4, 5-dimethylthiazol-2-yl)-2, 5-diphenyltetrazolium bromide] [18]. $5 \times 10^{3}$ cells were plated in each well of 96 well plate in triplicate, treated with and without UR6 at varying concentration ranging from $0-10^{9}$ cells $/ \mathrm{ml}$ of media for $0-48 \mathrm{~h}$, and treated with $20 \mu \mathrm{lof} 5 \mathrm{mg} / \mathrm{ml}$ MTT stock solution. After incubation for $4 \mathrm{~h}$ at $37^{\circ} \mathrm{C}$ the formazan crystals were made soluble by isopropanol and the color was measured at $595 \mathrm{~nm}$ using an ELISA reader (Model: Emax, Molecular device, USA).

\section{Assessment of cell morphology}

Six-well tissue culture plates or $35 \mathrm{~mm}$ dishes were seeded with cells $\left(3 \times 10^{4} /\right.$ well $)$, which were grown to $75 \%$ confluency and treated with varying concentration of UR6 for $0-48 \mathrm{~h}$. The cells were observed under inverted phase contrast microscope (Model: OLYMPUS IX 70, Olympus Optical Co. Ltd., Shibuya-ku, Tokyo, Japan) and photographs were taken with a digital camera (Olympus, Inc. Japan).

\section{Fluorescence microscopy}

Chromatin condensation and nuclear damage due to UR6 addition was assayed by fluorescence microscopy. Treated and untreated cells were stained with $10 \mu \mathrm{g} / \mathrm{ml}$ of DAPI and observed under fluorescence microscope (Model: OLYMPUS IX70, Olympus Optical Co. Ltd., Shibuya-ku, Tokyo, Japan) with excitation at $359 \mathrm{~nm}$ and emission at $461 \mathrm{~nm}$. Acridine orange $(50 \mu \mathrm{g} / \mathrm{ml})$ and Ethidium bromide $(50 \mu \mathrm{g} /$ $\mathrm{ml}$ ) stainings were done to distinguish between live, apoptotic and necrotic cells [19] and the stained cells were observed under fluorescence microscope with excitation at $488 \mathrm{~nm}$ and emission at $550 \mathrm{~nm}$.

\section{Quantification of apoptotic cell death}

AnnexinV-FITC Apoptosis detection kit (Calbiochem, Germany) was used to detect apoptosis. Treated and untreated cells were stained with FITC coupled Annexin V and PI as per instruction. Stained cells $\left(10^{4}\right)$ were analyzed by BD LSR Fortessa cell analyzer. Apoptosis was detected spectrophotometrically by using an ELISA based detection system (Cell Death Detection ELISA11544675001 of Roche Molecular Biochemicals (Mannheim, Germany).

\section{Cell cycle arrest assay}

Treated and untreated cells were harvested and resuspended in $50 \mu$ l cold PBS. These were treated with $70 \%$ pre-chilled methanol, incubated at $-20^{\circ} \mathrm{C}$, and washed with cold PBS. Then RNase was added, incubated for $30 \mathrm{~min}$, treated with propidium iodide [20], and analyzed by FACSCalibur instrument (BD Biosciences, San Jose, CA).

Assay for Caspases

ELISA based colorimetric assay kit was used to assay caspase-3 and caspase-9 (Santa Cruz Biotechnology) as per the manufacturer's protocol.

\section{Western blot analysis}

Western blot analysis was performed with minor modification of [21]. Thus $40 \mu \mathrm{g}$ of proteins isolated from both treated and untreated cells were electrophoretically separated in SDS-polyacrylamide gel and transferred to PVDF membrane (Immobilon-P, Millipore Corporation, Bedford, MA, USA) by using semidry trans-blot system (Transblot SD: Semidry transfer cell; Bio-Rad Laboratories, Inc., Hercules, CA, USA). Membranes were blocked with BSA or non-fat dry milk and incubated with primary antibodies overnight. After extensive washing the membranes were incubated with AP or HRP conjugated secondary antibodies. Immuno-reactive bands were visualized by adding proper substrates. $\beta$-Actin and Lamin A were used as loading controls. 


\section{Cellular Physiology Cell Physiol Biochem 2016;38:1303-1318

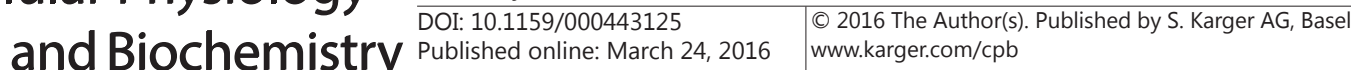 \\ Bose et al.: Attenuated Leishmania Induces Apoptosis of HepG2 Cells}

Measurement of mitochondrial membrane potential

Rhodamine 123 was used to assay mitochondrial membrane potential (MMP). Treated and untreated cells were washed with PBS and incubated with Rhodamine $123(5 \mu \mathrm{g} / \mathrm{ml})$ in the dark for $15 \mathrm{~min}$ at $37^{\circ} \mathrm{C}$ and fluorescence was checked by a spectrofluorometer (LS50B; Perkin Elmer) using fluorescence wave length of $535 \mathrm{~nm}[22]$.

Measurement of ROS generation

DCF-DA was used to estimate ROS generation. Treated and untreated cells were washed with PBS, treated with $10 \mathrm{mM}$ DCF-DA, and incubated at $37^{\circ} \mathrm{C}$ for $15 \mathrm{~min}$ [23]. Increasing concentration of NAC, a inhibitor of ROS production, was added to HepG2 cells treated with $2 \times 10^{7}$ UR6 cells $/ \mathrm{ml}$ of media. DCFDA is cleaved by ROS to produce the fluorescent $2^{\prime}, 7^{\prime}$-dichlorofluorescein (DCF), which was analysed by FACSCalibur flowcytometry (Becton Dickinson, San Jose, CA, USA) with excitation at $480 \mathrm{~mm}$ and emission at $515 \mathrm{~nm}$.

Measurement of Calcium release

Both treated and untreated cells were harvested, washed twice with PBS, treated with FURA 2 AM (Molecular Probes) as specified by the manufacturer, and incubated for $45 \mathrm{~min}$ at $37^{\circ} \mathrm{C}$. The cells were washed with PBS, resuspended in fresh PBS, and analyzed at an excitation wave length of $380 \mathrm{~nm}$ and an emission wave length of $510 \mathrm{~nm}$ using a flow cytometer of Becton Dickinson (San Jose, CA, USA).

\section{Immunocytochemistry Study}

For immunocytochemistry, treated and untreated cells in cover slips were washed with PBS and fixed by $4 \%$ paraformaldehyde. Fixed cells were permeabilized by treating with $0.2 \%$ Tween 20 in a blocking solution containing 2\% BSA at room temperature for $20 \mathrm{~min}$ [24]. Cells in the cover slips were stained with primary antibodies [viz. rabbit anti p53-p392 (Cell signaling), gp91 (Santa Cruz), p53-p46 (Cell signaling), mouse anti p53 (Santa Cruz), p21 (Cell signaling), Bax (Santa Cruz), and cytochrome C (Santa Cruz) polyclonal antibody] at concentration 1:150, and washed with washing buffer. Then TRITC and FITC conjugated secondary antibodies at concentration 1:300 were added to it. Secondary antibodies are washed and fixed in the glass slide. The mitochondria were stained with Mito tracker (Life Technologies) as per manufacturer's instructions. DAPI was used to counterstain the genomic DNA and imaging was done using Nikon Eclipse C1 confocal microscope and Andor Spinning Disc Confocal microscope.

Intracellular marker staining for flow cytometric study

For intracellular marker staining, the cells were washed with $1 \% \mathrm{v} / \mathrm{v}$ FBS-PBS (staining buffer) and fixed in $4 \% \mathrm{w} / \mathrm{v}$ paraformaldehyde $\left(20 \mathrm{~min}\right.$ at $\left.4^{\circ} \mathrm{C}\right)$. Cells were washed with PBS, permeablised by $0.1 \%$ saponin in PBS, and incubated with p53-p46 (Cell signaling), cleaved PARP (Cell signaling), or p53-p392 (Cell signaling) and p53 (Santa Cruz) specific primary antibodies for $1 \mathrm{~h}$ at $4^{\circ} \mathrm{C}$ [23]. Fluorophore tagged secondary antibodies were added and incubated for $45 \mathrm{~min}$ at $4^{\circ} \mathrm{C}$. After adding $10 \mathrm{mM}$ DCF-DA solution, it was resuspended in $1 \mathrm{ml}$ PBS and analyzed by FACSCalibur flowcytometry (Becton Dickinson, San Jose, CA, USA).

Statistical analysis

Values reported were mean \pm SE and the statistical significance was determined by Student's t test.

\section{Results}

Cytotoxic effect of Leishmania donovani UR6

HepG2 cell line was treated with UR6 at concentrations ranging from 0 to $10^{9} \mathrm{cells} / \mathrm{ml}$ of media for $0-48 \mathrm{~h}$ (Fig. $1 \mathrm{~A}$ ) to find that the $\mathrm{IC}_{50}$ value for $24 \mathrm{~h}$ lies within $10^{7}$ cells $/ \mathrm{ml}$ of media. To specify the optimum concentration, different doses ranging from $1 \times 10^{7}$ to $8 \times 10^{7}$ cells $/ \mathrm{ml}$ of media were also analyzed (Fig. 1B) and from this a specific dose of $4 \times 10^{7}$ cells / $\mathrm{ml}$ of media was selected as optimum for $24 \mathrm{~h}$. At this dose, $65 \%$ cell death was observed within 24 h. Leishmania major, shown by Hedayatollah et al. [16] to have no cytotoxicity on 


\section{Cellular Physiology Cell Physiol Biochem 2016;38:1303-1318

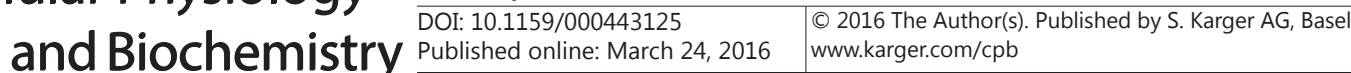

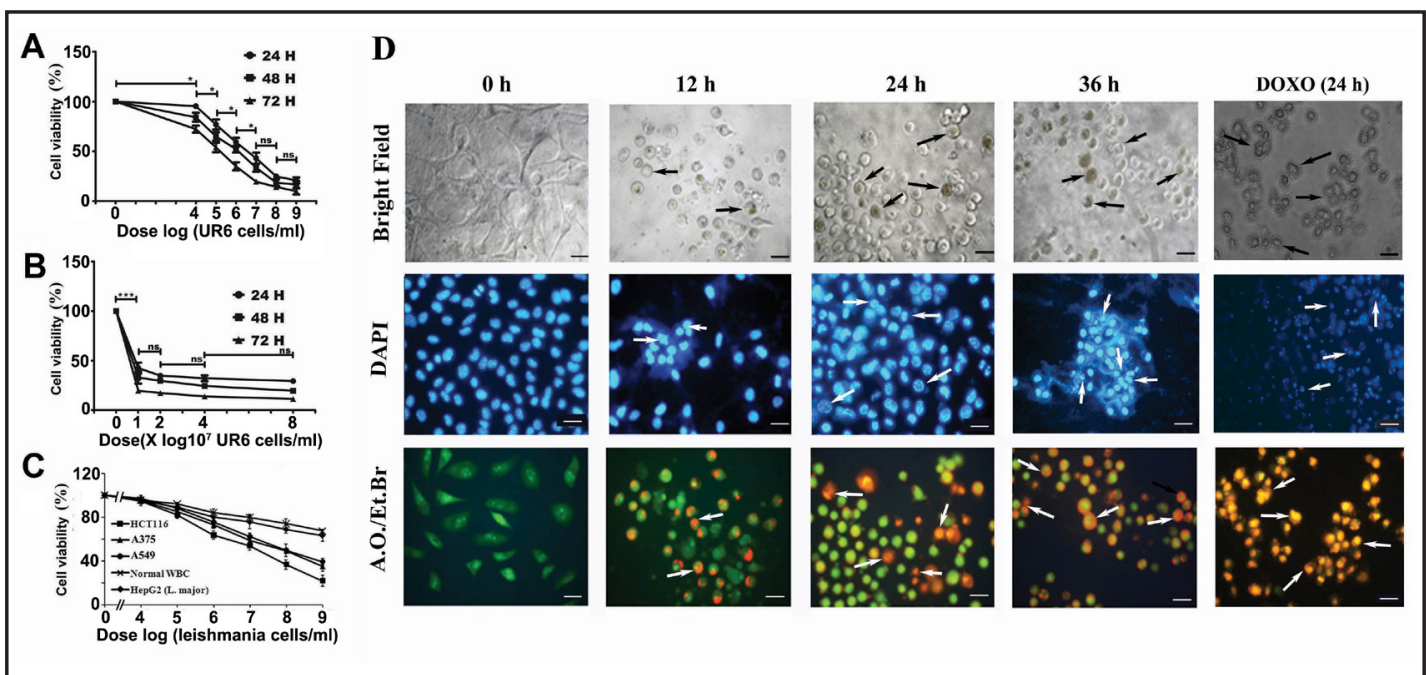

Fig. 1. Growth inhibitory effect of attenuated Leishmania donovani UR6 on HepG2. Number of UR6 cells were calculated by haemocytometer and added to mammalian cell culture to make final mentioned concentration (A) and (B). Cells were treated with different concentrations ( $0-1 \times 10^{9}$ cells $\left./ \mathrm{ml}\right)$ of UR6 for 24 , 36 and $48 \mathrm{~h}$ and viability were measured by MTT assay. (C) Cytotoxic effect of UR6 on different cell lines, namely, HCT116, A375, and A549, and on normal blood cells. HepG2 cells were treated with Leishmania major as negative control at different concentrations and cytotoxicity was studied by MTT. (D) Morphological and nuclear changes in HepG 2 cells after addition of $4 \times 10^{7}$ UR6 cells/ml for 0, 12, 24, $36 \mathrm{~h}$. Upper row: Morphological changes seen under light microscope. Middle and lower row: Nuclear changes seen under fluorescence microscope after DAPI and A.O./EtBr staining respectively. Doxorubicin (10 $\mu \mathrm{g} / \mathrm{ml})$ is used as a positive control. The arrows indicate cell rounding and DNA fragmentation, and acidification of the cytoplasm. Each size bar represents $100 \mu \mathrm{m}$. All the experiments were done in triplicate and are reported as the mean \pm SD of triplicate experiments $\left(* \mathrm{P}<0.05\right.$, ${ }^{* *} \mathrm{P}<0.01$, *** $\left.\mathrm{P}<0.001\right)$.

fibrosarcoma and used as negative control, showed minimum cytotoxicity on HepG2 cells (Fig. 1C). UR6 was also found to induce apoptosis cytotoxicity on HCT116, A549 and A375 cells (Fig. 1C). However, it showed minimum cytotoxicity against normal WBC isolated from blood ( $\mathrm{p}<0.05)$.

When HepG2 cells were treated with $2 \times 10^{7}$ UR6 cells/ml of media for $0,12,24$ and 48 $\mathrm{h}$ on and stained with either Acridine orange-EtBr or DAPI, there were significant changes in the morphology of the cells (Fig. 1D). With increasing time, cells appeared rounded with fragmented nuclei as evident from DAPI staining. Doxorubicin induced apoptosis in HepG2 cells.

Leishmania donovani UR6 enhances Annexin V positive cells population in HepG2 cells with cell cycle arrest at G1 phase

Phosphatidyl serine (PS) exposure in the outer membrane of HepG2 cells, which occurs during the initial phase of apoptosis, was measured in time dependent manner (from 0 to $48 \mathrm{~h}$ ) by flow cytometric analysis of the UR6 treated HepG2 cells using Annexin V-FITC. This showed that the total percentage of Annexin $V$ negative cells decreased with time and the total number of apoptotic cells increased compared to control. This study confirms that UR6 induces apoptosis in HepG2 cells (Fig. 2A). Doxorubicin used as a positive control (data not shown).

It is known that cells are arrested at any phase of the cycle and are finally destined for death when any un-repairable damage occurs to them as they are passing through the cell cycle. The status of cell cycle arrest by UR6 on HepG2 cells was therefore monitored by flow cytometric analysis using PI. Incubation of $4 \times 10^{7}$ cells $/ \mathrm{ml}$ of media for $0-48 \mathrm{~h}$ showed increasing number of cells at G1 phase. This study indicated that UR6 induces apoptosis of 


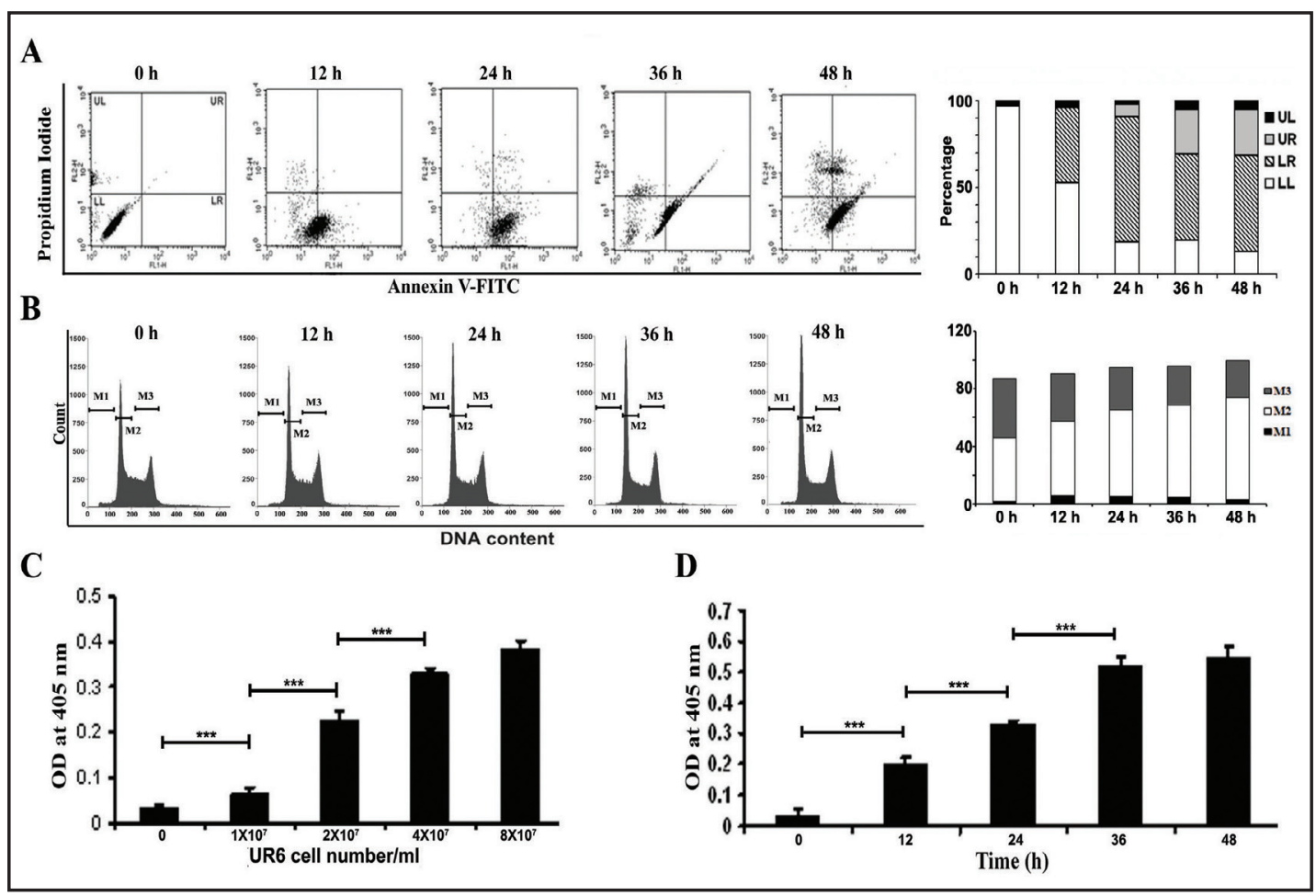

Fig. 2. Effect of UR6 on HepG2 cells in inducing apoptosis, cell cycle arrest and DNA fragmentation. (A) Annexin V-FITC binding, and (B) cell cycle arrest, (C and D). DNA fragmentation in HepG2 cells. For A and $\mathrm{B}$, addition of $4 \times 10^{7}$ cells $/ \mathrm{ml}$ of UR6 was done for $0,12,24,36$ and $48 \mathrm{~h}$. M1, M2, M3 represent G0, G1 and G2/M phases respectively. (C) HepG2 cells were treated with UR6 $\left(0,1 \times 10^{7}, 2 \times 10^{7}, 4 \times 10^{7}\right.$ and $8 \times 10^{7}$ cells/ml) for $24 \mathrm{~h}$ and DNA fragmentation was assayed. (D) HepG2 cells were treated with UR6 $\left(4 \times 10^{7}\right.$ cells/ml) for $0,12,24,36$ and $48 \mathrm{~h}$ and DNA fragmentation (expressed as 0.D.) were assayed. For All the experiments were done in triplicate and are reported as the mean \pm SD of triplicate experiments $(* \mathrm{P}<0.05$, ** $\mathrm{P}<0.01$, *** $\mathrm{P}<0.001)$.

HepG2 cells probably through cell cycle arrest at G1 phase (Fig. 2B). The status of different cell cycle regulatory proteins were then studied (Fig. 5H). Cyclins D1, D2 and E were found to be down-regulated, accompanied by suppression of phosphorylation of retinoblastoma protein. This change in cell cycle regulatory proteins indicates that cell cycle arrest at G1 induced apoptosis of HepG2 cells by UR6.

\section{Quantification of DNA fragmentation}

UR6 was found to increase DNA fragmentation in HepG2 cell lines in a concentrationdependent manner (Fig. 2C). Performing a quantitative analysis, significant effect was observed after $24 \mathrm{~h}$ of incubation which increased up to $48 \mathrm{~h}$ ( $\mathrm{p}<0.05)$ (Fig. 2D).

UR6 induced apoptosis in HepG2 cells involves mitochondrial pathway

Apoptosis normally involves intrinsic (mitochondrial) or extrinsic pathway or both. To test for the involvement of mitochondrial pathway, levels of Bax, cleaved caspases 9 and 3, anti-apoptotic Bcl-2, and cleaved PARP were determined (Fig. 3A). Colorimetric assay revealed increase in levels of caspases 3 and 9 with increasing concentrations of UR6 (Fig. 3B) ( $\mathrm{p}<0.05)$. To confirm the role of caspases in UR6 induced apoptosis of HepG2 cells, the percent cell death in presence of the caspase inhibitors was examined. Addition of Z-DEVDFMK and Z-LEHD-FMK $1 \mathrm{hr}$ prior to UR6 challenge lowered the cytotoxicity. Incubation of 4 $\times 10^{7}$ cells $/ \mathrm{ml}$ of media for $24 \mathrm{~h}$ decreased cell viability, and this effect was inhibited in the presence of the specific caspase inhibitors (Fig. 3C) $(\mathrm{p}<0.05)$.

\section{KARGER}




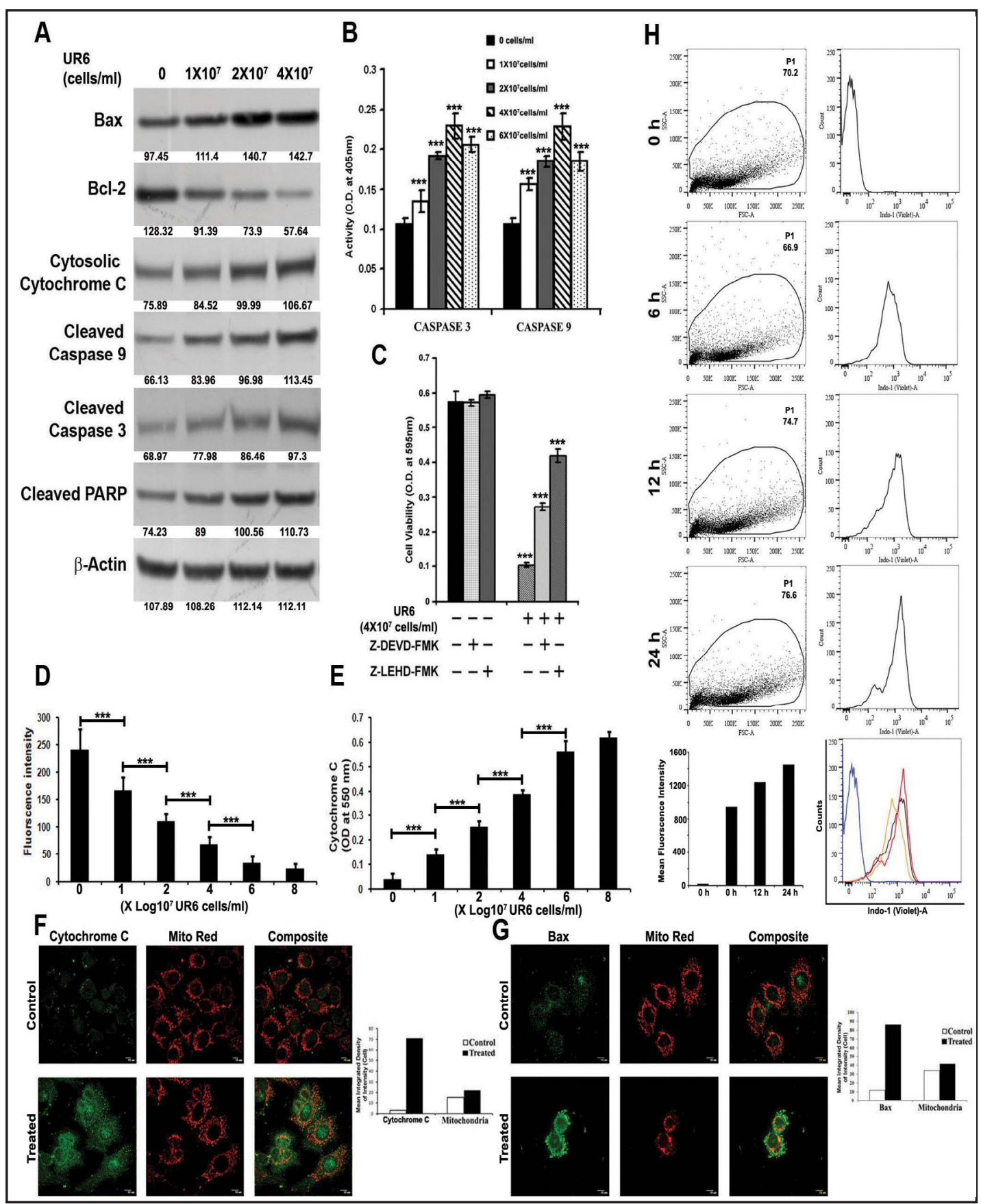

Fig. 3. Involvement of mitochondrial pathway in UR6 treated HepG2 cells. (A) Status of pro- and anti-apoptotic proteins related to mitochondrial pathway after addition of UR6 or none for $24 \mathrm{~h}$. The band intensities was measured by Photoshop CS3 and mentioned below each band (AU). (B) Caspase-3 and Caspase-9 levels following treatment of increasing concentrations $\left(0,1 \times 10^{7}, 2 \times 10^{7}, 4 \times 10^{7}\right.$ and $6 \times 10^{7}$ cells $\left./ \mathrm{ml}\right)$ of UR6 for $24 \mathrm{~h}$. (C) Cytotoxicity of UR6 for $24 \mathrm{~h}$ in presence of specific inhibitors of caspases 3 and 9. (D and E) Mitochondrial membrane potential and cytosolic cytochrome $\mathrm{C}$ level in response to $24 \mathrm{~h}$ treatment with indicated concentration of UR6. (F and G) Microscopic study of cytochrome C release in cytoplasm, expression of Bax and increase in number of mitochondria due to incubation of HepG2 cells with UR6. Each size bar represents $10 \mu \mathrm{m}$. Graphical presentation describes the change of mean fluorescence intensity. (H) Release of Calcium in the cytoplasm due to addition of $4 \times 10^{7}$ cells $/ \mathrm{ml}$ of UR6 for $0,6,12$ and $24 \mathrm{~h}$. The graphical presentation shows the increase in mean fluorescence. All the experiments were done in triplicate and are reported as the mean $\pm \mathrm{SD}$ of triplicate experiments $\left({ }^{*} \mathrm{P}<0.05,{ }^{* *} \mathrm{P}<0.01,{ }^{* * *} \mathrm{P}<0.001\right)$. 


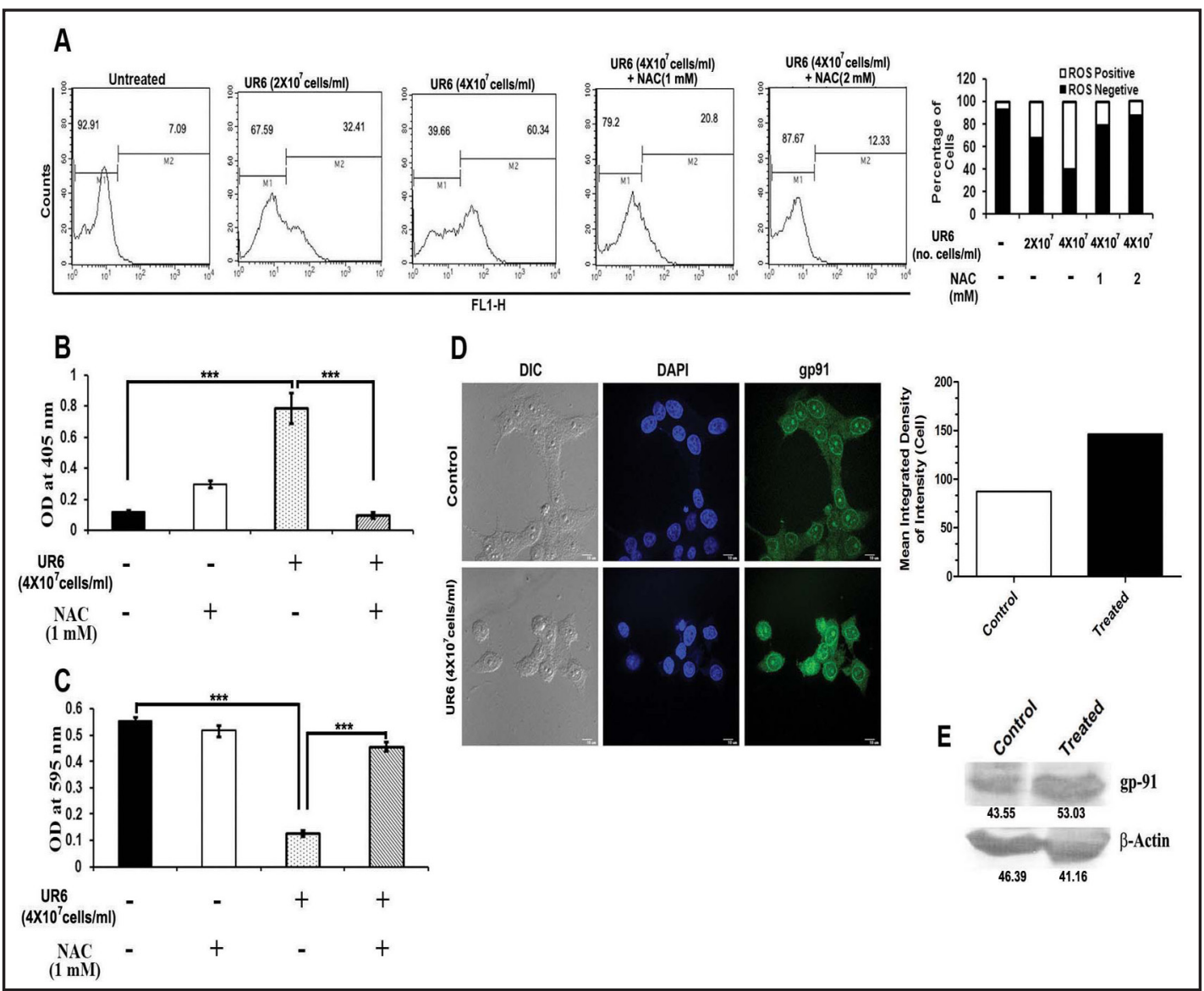

Fig. 4. ROS generation in HepG2 cells upon addition of $4 \times 10^{7}$ cells/ml of UR6 and the scavenging action by NAC. (A) Flow cytometric study of dose response of ROS generation by different concentrations (as indicated) of UR6 incubated for $24 \mathrm{~h}$ and the effect of increasing concentration of NAC ( $1 \mathrm{mM}$ and $2 \mathrm{mM}$ ) on UR6 treated cells showing the different degrees of scavenging effect. The graphical presentation depicts the percentage of ROS positive cells to ROS negative cells gated with respect to unstained control. (B) Effect of ROS generation on DNA fragmentation as measured by colorimetric assay. (C) Cell viability after treatment with $4 \times 10^{7}$ cells $/ \mathrm{ml}$ of UR6 and its alteration by NAC treatment. (D) Microscopic study of expression of gp91 due to treatment of UR6 in HepG2 cells. Each size bar represents $10 \mu \mathrm{m}$. Graphical presentation reveals the change of mean fluorescence intensity. (E) Western blot analysis showing change of expression of gp91 due to addition of $4 \times 10^{7}$ cells/ml of UR6 as analysed by western blotting and the band intensities was measured by Photoshop CS3 and mentioned below each band (AU). All the experiments were done in triplicate and are reported as the mean $\pm \mathrm{SD}$ of triplicate experiments $\left(* \mathrm{P}<0.05,{ }^{* *} \mathrm{P}<0.01,{ }^{* * *} \mathrm{P}<0.001\right)$.

Quantification of mitochondrial membrane potential and release of calcium and cytochrome $C$ in the cytosol

Cytotoxicity of UR6 on HepG2 cells was also confirmed by measuring the loss of mitochondrial membrane potential (Fig. 3D) and the release of cytochrome $\mathrm{C}$ in the cytosol (Fig. 3E), and this was confirmed by confocal images (Fig. 3F) $(p<0.05)$. Apoptosis was marked with increased concentration of Bax in the cytoplasm. UR6 also upregulated Bax in the cytoplasm as evident from the immuno-cytochemistry study (Fig. 3G).

FURA2 binds to free calcium and gives fluorescence at $355-360 \mathrm{~nm}$. Flow cytometric analysis revealed that the level of free calcium increased with time from $0-24 \mathrm{~h}$ following incubation with UR6 (Fig. 3H). 


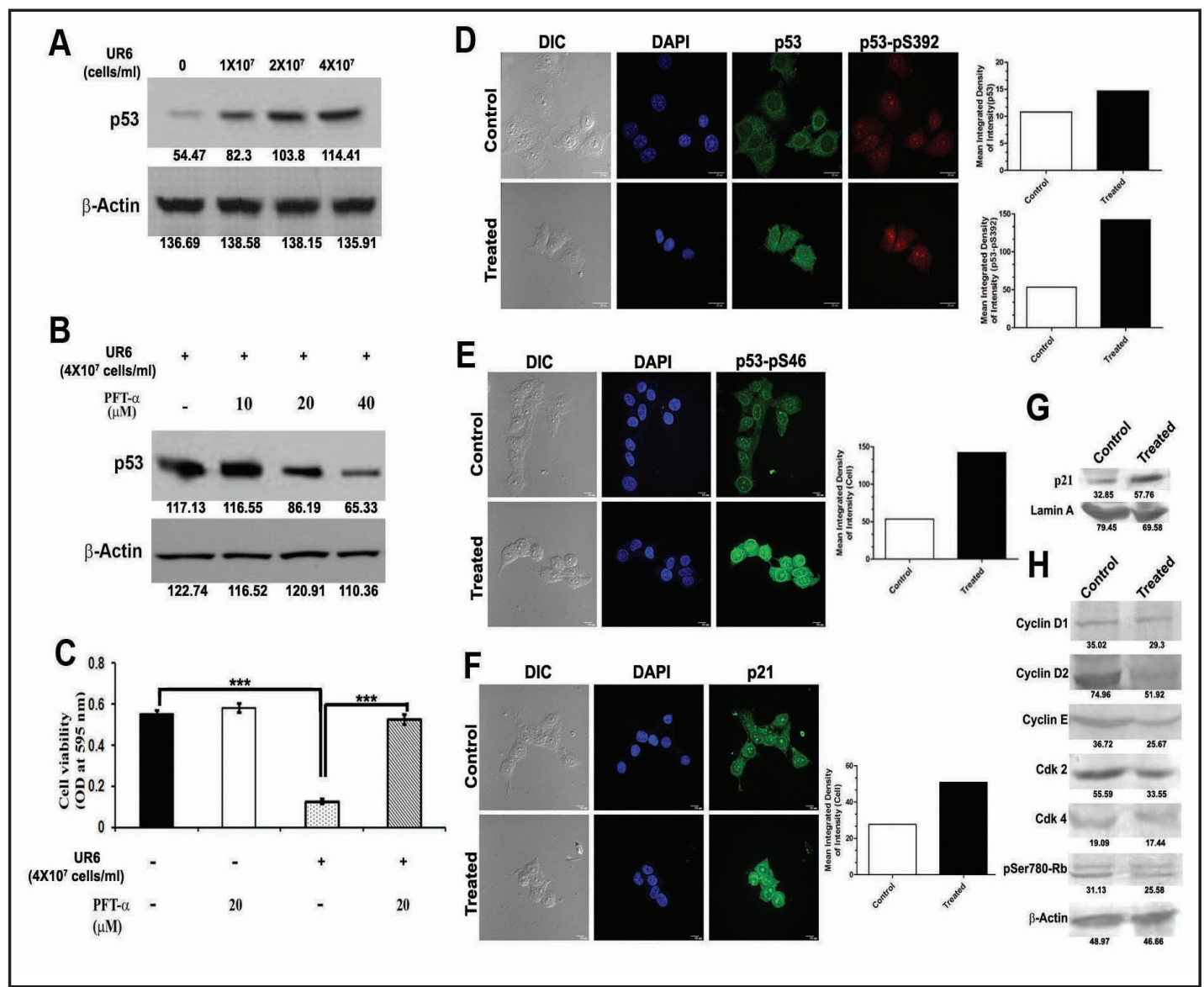

Fig. 5. Upregulation of p53 and other G1 cell cycle proteins in HepG2 cells upon addition of UR6. (A) Western blot analysis of p53 production on increasing concentration of UR6 treatment. (B) Western blot analysis showing the effect of increasing concentration of PFT- $\alpha$ on UR6 treated HepG2 cells. The band intensities was measured by Photoshop CS3 and mentioned below each band (AU) (C) Cell viability after addition of 4 $\times 10^{7}$ cells/ml of UR6 for $24 \mathrm{~h}$ and its alteration by PFT- $\alpha$ treatment. (D, E, and F) Microscopic study of the expressions of (D) p53 (green) and p53-pS392 (red), (E) p53-pS46 (green), and (F) p21 (green) due to UR6 addition $\left(4 \times 10^{7}\right.$ cells $\left./ \mathrm{ml}\right)$ for $24 \mathrm{~h}$. Each size bar represents $10 \mu \mathrm{m}$. Graphical representation shows the change of mean fluorescence intensity. ( $G$ and $H$ ) Western blot analysis of the change of status of p21 and different cell cycle check point proteins like CyclinD1, CyclinD2, CyclinE, Cdk2, Cdk4, pSer780Rb and $\beta$-Actin (loading control) due to addition of $4 \times 10^{7} \mathrm{cells} / \mathrm{ml}$ of UR6 for $24 \mathrm{~h}$. The band intensities were measured by Photoshop CS3 and mentioned below each band (AU). All the experiments were done in triplicate and are reported as the mean $\pm \mathrm{SD}$ of triplicate experiments $\left({ }^{*} \mathrm{P}<0.05,{ }^{* *} \mathrm{P}<0.01,{ }^{* * *} \mathrm{P}<0.001\right)$.

\section{UR6 induces apoptosis by ROS generation}

Reactive oxygen species (ROS) plays a key role in inducing apoptosis. Indeed flow cytometric analysis proved that increasing concentration of UR6 boosted ROS production in HepG2 cells and thus induced apoptosis. It is known that NAC positively inhibits ROS generation and this is evident from Fig. 4A. HepG2 cells that are pretreated with NAC $1 \mathrm{~h}$ prior to UR6 treatment showed considerably less ROS positive cells. Excess ROS production is associated with DNA damage and subsequent cell death. UR6 produces ROS that causes DNA damage. On NAC treatment DNA damage and cellular cytotoxicity were almost same as that of UR6 untreated cells. This reveals that UR6 induces ROS generation that is responsible for DNA damage and in turn induces cell death (Fig. 4B, 4C) (p<0.05).

On the other hand, Gp91 is considered as responsible for ROS production. Gp91 is a constituent of cytochrome b558, which is essential for NADPH activity. The assembled

\section{KARGER}




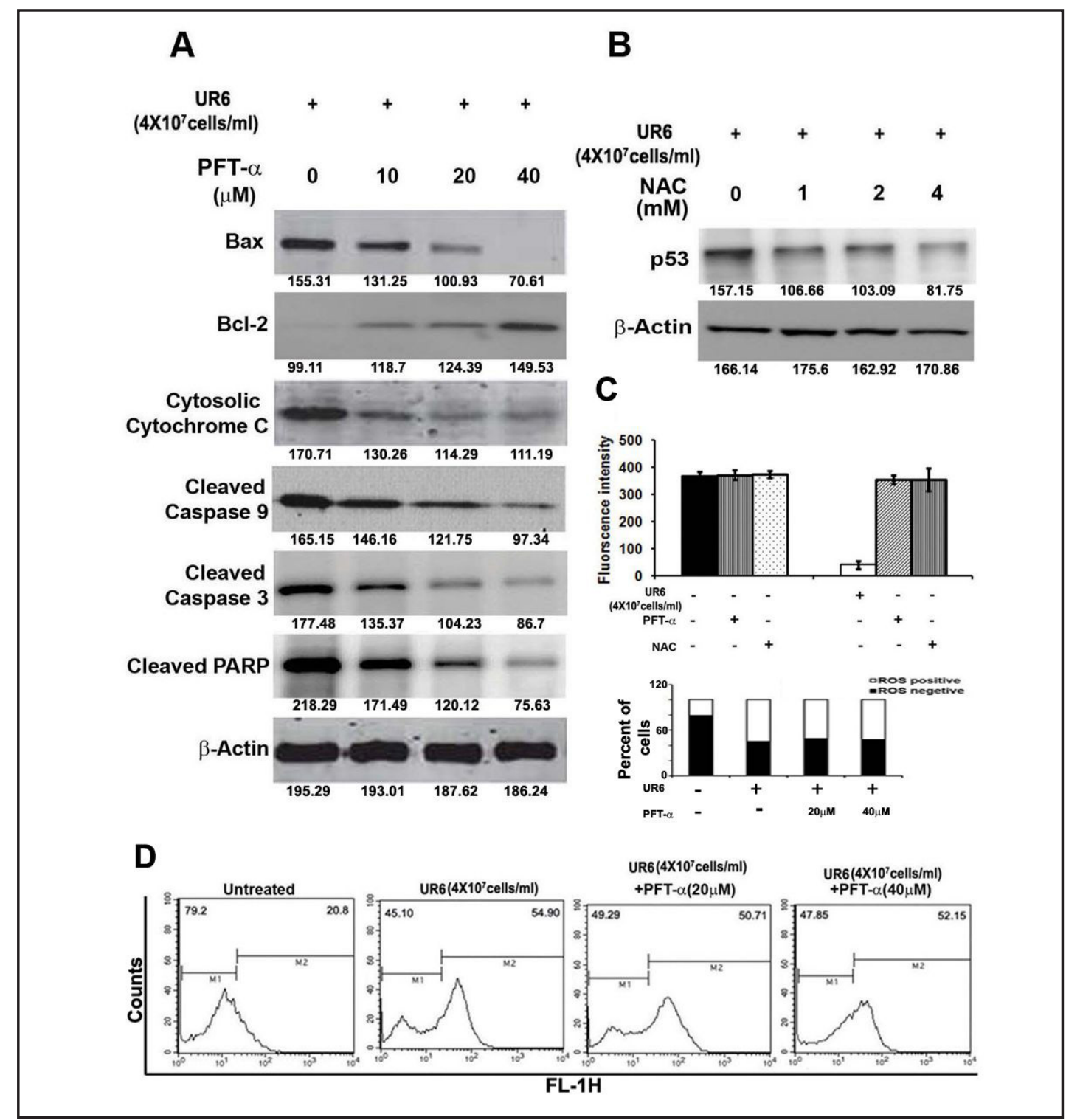

Fig. 6. UR6 induces cell death through p53 and ROS mediated pathway. (A) HepG2 cells, pre-treated with increasing concentration $(0,10,20,40 \mu \mathrm{M})$ of PFT- $\alpha$, were treated with UR6 $\left(4 \times 10^{7} \mathrm{cells} / \mathrm{ml}\right)$ for $24 \mathrm{~h}$ and western blot of the pro and anti apoptotic markers of mitochondrial pathway were performed. (B) Western blot analysis showing the effect of increasing concentration of NAC $(0,1,2,4 \mathrm{mM})$ on UR6 $\left(4 \times 10^{7}\right.$ cells/ $\mathrm{ml})$ treated HepG2 cells. The band intensities was measured by Photoshop CS3 and mentioned below each band (AU). (C) Effect of PFT- $\alpha$ and NAC on mitochondrial membrane potential of UR6 $\left(4 \times 10^{7}\right.$ cells $\left./ \mathrm{ml}\right)$ treated HepG2 cells as determined by spectrofluorometer. (D) Flow cytometric analysis of ROS generation on HepG2 cells pre-treated with PFT- $\alpha$. Graphical representation shows the proportion of ROS positive cells to that of ROS negative cells.

enzyme complex facilitates electron transfer from NADPH to molecular oxygen, leading to the generation of superoxide anions, which subsequently react to form ROS such as hydrogen peroxide and hydroxyl radicals [25]. UR6 treatment positively regulated Gp91 production as evident from microscopic study (Fig. 4D) and western blot analysis (Fig. 4E). The intensity profile for microscopic study is represented graphically.

\section{KARGER}




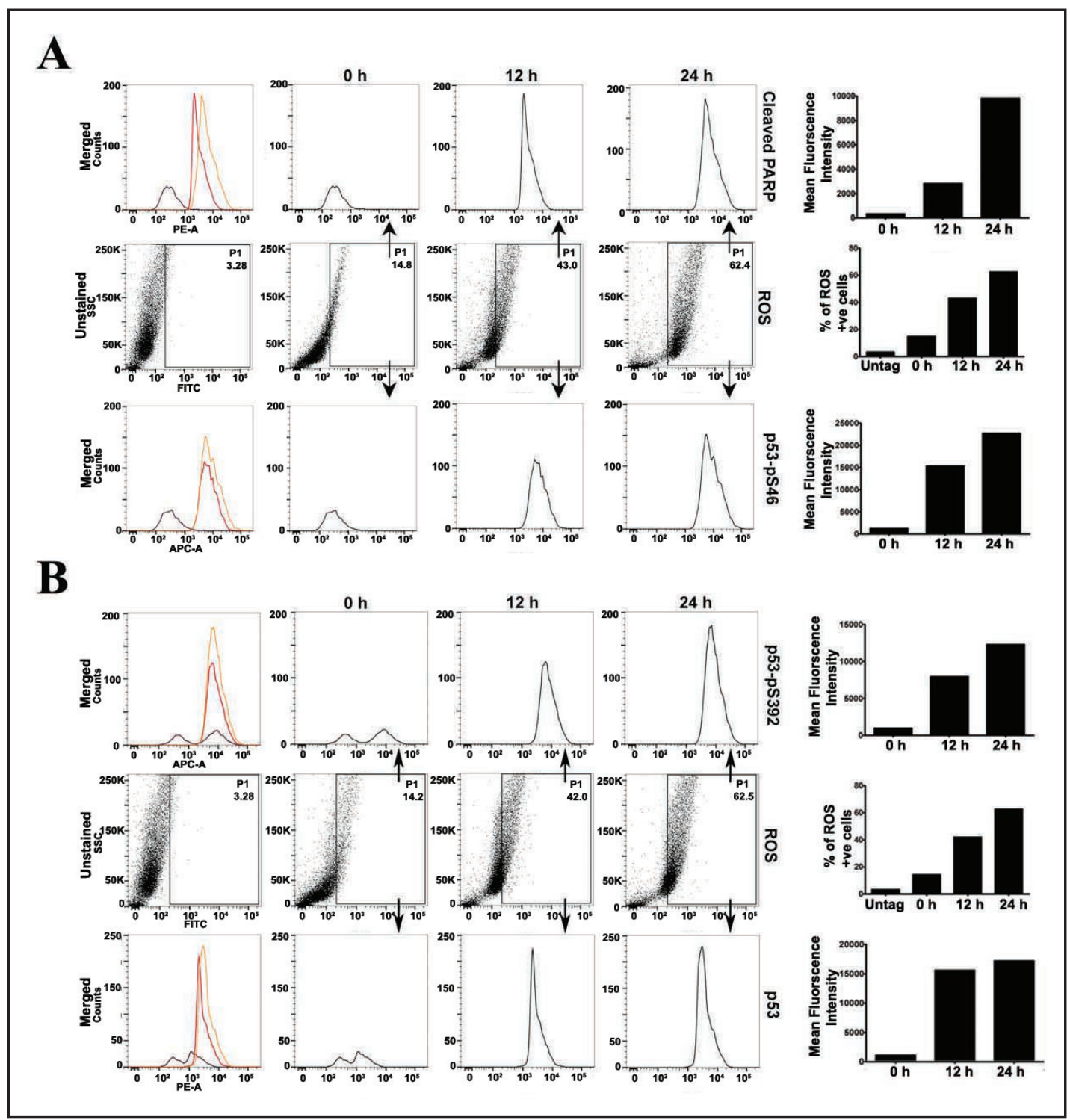

Fig. 7. UR6 induces ROS generation and ROS positive cells selectively show upregulation of apoptotic markers. (A and B) HepG2 cells were treated with $4 \times 10^{7}$ cells/ml of UR6; after 0,12 , and $24 \mathrm{~h}$, ROS positive cells were gated and the expressions of cleaved PARP, p53, p53-pS46 and p53-pS392 were analysed by a flowcytometer. The data were represented graphically. The experiment was performed thrice and one of the representative data was presented.

Dependence of p53 on cytotoxicity of UR6 on HepG2 cells

Protein p53, known as a tumor suppressor, is upregulated during apoptosis. There are at least seven phosphorylation sites of p53, of which serine 392 and serine 46 are important for apoptosis induction and oxidative stress respectively. Incubation with increasing concentration of UR6 increased the production of native p53 as evident from western blot (Fig. 5A).

Addition of the p53inhibitor PFT- $\alpha$ prior to UR6 incubation not only decreased p53 production (Fig. 5B) but also increased cell viability. UR6 $\left(4 \times 10^{7}\right.$ cells $/ \mathrm{ml}$ of media) incubation decreased the cell viability to $25-30 \%$. But on PFT- $\alpha$ treatment the figure was almost the same as that of untreated control (Fig. 5C) ( $p<0.05)$. UR6 $\left(4 \times 10^{7}\right.$ cells $/ \mathrm{ml}$ of media) showed minimum cytotoxicity on p53 siRNA treated HepG 2 cells and p53\% HCT116 


\section{Cellular Physiology Cell Physiol Biochem 2016;38:1303-1318 \begin{tabular}{l|l} 
and Biochemistry Published online: March 24, 2016 & $\begin{array}{l}\text { DO } 2016 \text { The Author(s). Published by S. Karger AG, Basel } \\
\text { www.karger.com/cpb }\end{array}$
\end{tabular} \\ Bose et al.: Attenuated Leishmania Induces Apoptosis of HepG2 Cells}

cells, while it was found to induce apoptosis in HCT116 cells for $24 \mathrm{~h}$ as evident from annexinV binding study (data not shown). Microscopic study after UR6 treatment showed the up-regulation of p53 and p53 phosphorylated at serine 392 (Fig. 5D), and of increased ser46 phosphorylation of p53, which is associated oxidative stress (Fig. 5E).

Protein p53 acts as a transcription factor and transcribes many genes including p21 which arrests cell cycle at G1 phase. UR6 was observed to up-regulate p21 as evident from microscopic studies (Fig. 5F) and western blot analysis (Fig. 5G).

UR6 mediates cell death through ROS dependent p53 mediated mitochondrial pathway

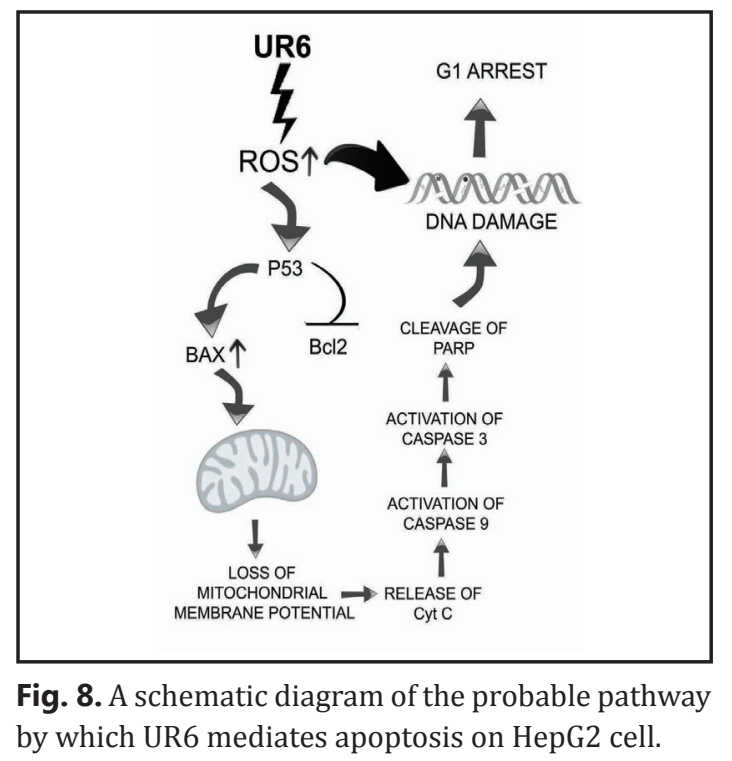

Cells pretreated with PFT- $\alpha$, which is known to inhibit p53 upregulation, showed lesser amounts of Bax, cytosolic cytochrome $\mathrm{C}$, cleaved caspases 3 and 9 and cleaved PARP, and increased amount of Bcl 2 (Fig. 6A). Increasing concentration of NAC was also found to inhibit p53 expression (Fig. 6B). Though PFT- $\alpha$ and NAC were found to prevent mitochondrial membrane potential loss caused by UR6 (Fig. 6C), pretreatment of cells with PFT- $\alpha$ did not have any effect on ROS generation. Flowcytometric study proved that this causes minimal or no change in ROS production (Fig. 6D), which clearly indicates that p53 is activated downstream of ROS production.

\section{ROS production is associated with p53 activation and PARP cleavage}

To study the involvement of ROS in activation of different molecules and in cell death, flow cytometric study was performed. DCF positive cells were selected and gated, and observed for different markers of apoptosis. UR6 treatment was found to increase the DCF positive (ROS positive) population. The selected population showed higher percentages of cleaved PARP, native p53, p53-pS46 and p53-pS392 (Fig. 7A and 7B). Cleavage of PARP is regarded as one of the positive markers of apoptosis. Thus this study revealed that UR6 induced oxidative stress, which in turn induced cell death via apoptosis.

\section{Discussion}

From the findings of these experiments, it is clear that heat killed Leishmania donovani UR6 decreases proliferation of HepG2 cells and increases cell death. The modus operandi behind this is programmed cell death, which is by far a safer mechanism of cell death in a living body from the system perspective. There are reports that few protozoa interfere with cancer cell growth or kill cancer cells by direct or indirect mechanisms [4-9, 16, 26]. Destroyed Typanosoma cruzi preparation was also shown to bring about cell death in neuroblastoma cells [27] where immune mechanism didnot play a role; instead direct selective effects of both trypanosomes and their preparations were demonstrated.

Cancer has been shown to weaken the immune system and approaches have been made to augment the immune response against cancer [28, 29]. Parasites like Plasmodium or antigens from T. gondi and T. canis had also been tried to provoke immune response against tumor model of mice with success $[6,30,31]$. But reports on direct killing of cancer cells by protozoa are limited $[5,8,26]$, particularly concerning those taking place following the path of apoptosis [26]. We have now succeeded in demonstrating that attenuated L. donovani causes apoptosis by p53 mediated pathway, in accordance with the hygiene theory $[32,33]$. 


\section{Cellular Physiology Cell Physiol Biochem 2016;38:1303-1318 \\ \begin{tabular}{l|l} 
and Biochemistry & DOI: 10.1159/000443125 \\
Published online: March 24, 2016 & $\begin{array}{l}\text { (c) 2016 The Author(s). Published by S. Karger AG, Basel } \\
\text { www.karger.com/cpb }\end{array}$
\end{tabular} \\ Bose et al.: Attenuated Leishmania Induces Apoptosis of HepG2 Cells}

To confirm that the mode of cell death is indeed apoptosis, classical apoptotic features of HepG2 cells were examined, for which morphological (fluorescence microscopy) and annexin V-FITC/PI-flow cytometry analysis were carried out. The classical apoptotic morphology of nuclear chromatin condensation and fragmentation was noted in HepG2 cells treated with heat killed Leishmania donovani UR6 (Fig. 1C and 2C, D). Apoptosis in HepG2 cells was thereby found to be mediated via the intrinsic pathway, where loss of mitochondrial membrane potential, increased release of cytochrome $\mathrm{C}$ in cytosol, activation of some proapoptotic molecules (Bax, cleaved caspase 9, caspase 3, and PARP), and down regulation of Bcl-2 happened in a dose dependent manner. Study of $\mathrm{Ca}^{2+}$ release showed increased release with time. We also carried out experiments to determine the role of caspases in the induction of apoptosis in HepG2 cells and found that inhibition of caspase 9 hampers cell death.

The detection of change in MMP level led us to investigate the possibility of apoptotic cell death occurring via ROS generation. Heat killed Leishmania donovani UR6 induced ROS mediated DNA fragmentation and cell death which was proved using NAC as an inhibitor of ROS. Next we carried out experiments to determine the involvement of p53, a tumor suppressor protein which is also a redox active transcription factor. Cellular ROS production is central to redox signaling and ROS can function as signaling molecule or cellular toxicant. Studies have revealed that p53 concentration, distribution and phosphorylation at various sites have distinguishable cellular functions. ROS acts as an upstream signal that activates p53 and as a downstream factor that mediates apoptosis [34,35]. We found upregulation and nuclear localization of native p53, p-ser46 p53 and p-ser392 p53 upon addition of UR6. Phosphorylation of p53 at Ser392 is increased in human tumors [36] and has been reported to influence the growth suppressor function, DNA binding and transcriptional activation of p53 [37-39], which regulates the ability of p53 to induce apoptosis [40]. To find out whether p53 induction by UR6 is under ROS surveillance or not, we checked p53 and ROS levels under NAC and PFT- $\alpha$ intervention. It was found that p53 is not critical for UR6 induced ROS generation (Fig. 6), but application of UR6 following NAC treatment significantly downregulated p53.

At physiological level p53 plays a minimal but vital role to contain ROS at nontoxic levels by maintaining basal transcription of several antioxidant proteins [41, 42]. But during overexpression, the hyperphysiological level of p53 regulates transcription of pro-oxidant genes including BAX. BAX may uncouple mitochondria resulting in loss of MMP, ROS being generated from a less efficient Electron transport chain [42]. So p53 and ROS plays a very crutial role in mitochondrial damage that leads to $\mathrm{Ca} 2+$ release in the cytosol and finally apoptosis induction in cancer cells [43-45]. A probable mechanism of apoptosis induction is schematically represented in Fig. 8.

UR6 also showed cytotoxic effect on three cancer cell lines, namely, HCT116, A549 and A375. While cytotoxic potential of $T$. cruzi has been reported earlier $[27,46]$, there seems to be no published evidence of apoptosis inducing potential of L. donovani, another trypanosoma. Rather anticancer drugs have been shown to have anti leishmanial activity [47]. Cruzin penetration was proved to be the mechanism behind the anticancer effect of trypanosoma on cancer cells [48] and disturbances in cellular respiration in malignant cell [48-51]. Recent research work also relates another trypanosoma to cancer biotherapy. An antioncogene (von Hippel-Lindau tumor suppressor gene) of human has been shown to have $40 \%$ identity with a surface protein of T. brucei [52]. Though the key factor behind the apoptosis inducing property of attenuated L. donovani UR6 remains to be identified, the present findings have brightened the possibility of trypanosomatid mediated anticancer therapy and showed that there may be molecular and genetic basis behind this phenomenon.

There are also some reports about different microbial components showing anti-cancer potential in a wide array of cancer cells and Azurin, a membrane bound protein is one such example that is already reported as a anticancer drug and right now in clinical trials [53]. Our study is also a preliminary attempt and in future it can lead to identification of new cellular components like membrane lipo-proteins that can have a potential anti-cancer activity. 


\section{Cellular Physiology Cell Physiol Biochem 2016;38:1303-1318 \begin{tabular}{cc|c} 
DOI: 10.1159/000443125 & (0 2016 The Author(s). Published by S. Karger AG, Basel \\
www.karger.com/cpb
\end{tabular} \\ Bose et al.: Attenuated Leishmania Induces Apoptosis of HepG2 Cells}

Bio-therapy against cancer is a notion generated long ago. But since then only the anticancer effect of Trypanosome cruzi has been reported. Though recent research had shown that von Hippel-Linadu tumor suppressor protein has $40 \%$ identity with a surface protein of T. cruzi, L. major has not been reported to have any anti-cancer property. In that scenario the discovery of cytotoxic potential of attenuated $L$. donovani UR6 would provide an impetus to the idea of biotherapy. Though the key stimulus behind initiation of the apoptotic cascade is yet to be explored, it seems that $L$. donovani, similar to trypanosome, modulates cellular respiration to bring about ROS production that induces p53 up-regulation, G1 arrest and subsequent apoptosis of cancer cells mediated by the mitochondrial pathway. The present findings of cytotoxic potential of UR6 would provide fillip to biotherapeutic treatments of cancer.

\section{Acknowledgements}

The authors convey their sincerest thank to Prof. Siddhartha Roy, the then Director of CSIR-Indian Institute of Chemical Biology, for providing us the necessary support for this work, and the Council of Scientific and Industrial Research (CSIR) and the Indian Council of Medical Research (ICMR) for financial assistance. We extend our sincere thanks to Dr. Suvendra Nath Bhattacharyya (CSIR-Indian Institute of Chemical Biology) and Mr. Diptadeep Sarkar for their help in confocal laser scanning microscopy. We are also thankful to Ms. Anushila Gangopadhyay for help in flow cytometeric study.

\section{Disclosure Statement}

The authors have declared that no competing interests exist.

\section{References}

1 Jemal A, Bray F, Center MM, Ferlay J, Ward E, Forman D: Global cancer statistics. CA Cancer J Clin 2011;61:69-90.

2 Nauts HC, Fowler GA, Bogatko FH: A review of the influence of bacterial infection and of bacterial products (coley's toxins) on malignant tumors in man; a critical analysis of 30 inoperable cases treated by coley's mixed toxins, in which diagnosis was confirmed by microscopic examination selected for special study. Acta Med Scand Suppl 1953;276:1-103.

3 Roskin Gr, Exempliarskaia E: Protozoeninfektion und experimenteller Krebs. Z Krebsforsch 1931;34:628645.

4 Atayde VD, Jasiulionis MG, Cortez M, Yoshida N: A recombinant protein based on trypanosoma cruzi surface molecule gp82 induces apoptotic cell death in melanoma cells. Melanoma Res 2008;18:172-183.

5 Kallinikova VD, Matekin PV, Ogloblina TA, Leikina MI, Kononenko AF, Sokolova NM, Pogodina LS: [anticancer properties of flagellate protozoan trypanosoma cruzi chagas, 1909]. Izv Akad Nauk Ser Biol 2001:299-311.

6 Kim JO, Jung SS, Kim SY, Kim TY, Shin DW, Lee JH, Lee YH: Inhibition of lewis lung carcinoma growth by toxoplasma gondii through induction of th1 immune responses and inhibition of angiogenesis. J Korean Med Sci 2007;22:S38-46.

7 Lopez NC, Valck C, Ramirez G, Rodriguez M, Ribeiro C, Orellana J, Maldonado I, Albini A, Anacona D, Lemus D, Aguilar L, Schwaeble W, Ferreira A: Antiangiogenic and antitumor effects of trypanosoma cruzi calreticulin. PLoS Negl Trop Dis 2010;4:e730.

8 Pidherney MS, Alizadeh H, Stewart GL, McCulley JP, Niederkorn JY: In vitro and in vivo tumoricidal properties of a pathogenic/free-living amoeba. Cancer Lett 1993;72:91-98. 


\section{Cellular Physiology Cell Physiol Biochem 2016;38:1303-1318

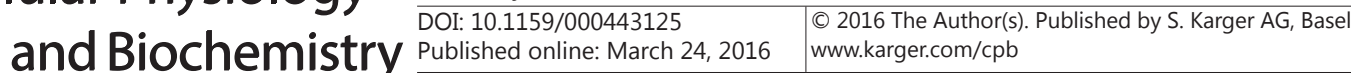 \\ Bose et al.: Attenuated Leishmania Induces Apoptosis of HepG2 Cells}

9 Plumelle Y, Gonin C, Edouard A, Bucher BJ, Thomas L, Brebion A, Panelatti G: Effect of strongyloides stercoralis infection and eosinophilia on age at onset and prognosis of adult t-cell leukemia. Am J Clin Pathol 1997;107:81-87.

10 Mukhopadhyay S, Bhattacharyya S, Majhi R, De T, Naskar K, Majumdar S, Roy S: Use of an attenuated leishmanial parasite as an immunoprophylactic and immunotherapeutic agent against murine visceral leishmaniasis. Clin Diagn Lab Immunol 2000;7:233-240.

11 Herrera B, Alvarez AM, Sanchez A, Fernandez M, Roncero C, Benito M, Fabregat I: Reactive oxygen species (ros) mediates the mitochondrial-dependent apoptosis induced by transforming growth factor (beta) in fetal hepatocytes. FASEB J 2001;15:741-751.

12 Sun X, Ai M, Wang Y, Shen S, Gu Y, Jin Y, Zhou Z, Long Y, Yu Q: Selective induction of tumor cell apoptosis by a novel p450-mediated reactive oxygen species (ros) inducer methyl 3-(4-nitrophenyl) propiolate. J Biol Chem 2013;288:8826-8837.

13 Simon HU, Haj-Yehia A, Levi-Schaffer F: Role of reactive oxygen species (ros) in apoptosis induction. Apoptosis 2000;5:415-418.

14 Ye J, Wang S, Leonard SS, Sun Y, Butterworth L, Antonini J, Ding M, Rojanasakul Y, Vallyathan V, Castranova V, Shi X: Role of reactive oxygen species and p53 in chromium(vi)-induced apoptosis. J Biol Chem 1999;274:34974-34980.

15 Cardaci S, Filomeni G, Rotilio G, Ciriolo MR: Reactive oxygen species mediate p53 activation and apoptosis induced by sodium nitroprusside in sh-sy5y cells. Mol Pharmacol 2008;74:1234-1245.

16 Shirzad H, Khorami S, Soozangar N, Yousefi M, Darani HY: Toxoplasma gondii but not leishmania major or trichomonas vaginalis decreases cell proliferation and increases cell death on fibrosarcoma cancer cells in culture medium. World J Vaccines 2012;2:105-108.

17 Mukhopadhyay S, Sen P, Bhattacharyya S, Majumdar S, Roy S: Immunoprophylaxis and immunotherapy against experimental visceral leishmaniasis. Vaccine 1999;17:291-300.

18 Mosmann T: Rapid colorimetric assay for cellular growth and survival: Application to proliferation and cytotoxicity assays. J Immunol Methods 1983;65:55-63.

19 Kern JC, Kehrer JP: Acrolein-induced cell death: A caspase-influenced decision between apoptosis and oncosis/necrosis. Chem Biol Interact 2002;139:79-95.

20 Deng Y, Wu X: Peg3/pw1 promotes p53-mediated apoptosis by inducing bax translocation from cytosol to mitochondria. Proc Natl Acad Sci USA 2000;97:12050-12055.

21 Towbin H, Staehelin T, Gordon J: Electrophoretic transfer of proteins from polyacrylamide gels to nitrocellulose sheets: Procedure and some applications. Proc Natl Acad Sci USA 1979;76:4350-4354.

22 Das S, Chatterjee N, Bose D, Dey SK, Munda RN, Nandy A, Bera S, Biswas SK, Das Saha K: Anticancer potential of 3-(arylideneamino)-2-phenylquinazoline-4(3h)-one derivatives. Cell Physiol Biochem 2012;29:251-260.

23 Chatterjee N, Das S, Bose D, Banerjee S, Jha T, Saha KD: Leishmanial lipid suppresses the bacterial endotoxin-induced inflammatory response with attenuation of tissue injury in sepsis. J Leukoc Biol 2014;96:325-336.

24 Chatterjee N, Das S, Bose D, Banerjee S, Chattopadhyay D, Saha KD: Exploring the anti-inflammatory activity of a novel 2-phenylquinazoline analog with protection against inflammatory injury. Toxicol Appl Pharmacol 2012;264:182-191.

25 Gorlach A, Brandes RP, Nguyen K, Amidi M, Dehghani F, Busse R: A gp91phox containing nadph oxidase selectively expressed in endothelial cells is a major source of oxygen radical generation in the arterial wall. Circ Res 2000;87:26-32.

26 Zhang XC, Cai NG, Sun L, Luo Q, An F: [apoptosis of human leukemia k562 cell in vitro induced by toxoplasma gondii]. Zhongguo Ji Sheng Chong Xue Yu Ji Sheng Chong Bing Za Zhi 2007;25:185-188.

27 Asahi H, Kawabata M, Moribayashi A, Okumura H: Cytotoxic factors toward neuroblastoma cells in trypomastigotes of trypanosoma cruzi. Can J Microbiol 1986;32:711-718.

28 Van den Heuvel MM, Burgers SA, van Zandwijk N: Immunotherapy in non-small-cell lung carcinoma: From inflammation to vaccination. Clin Lung Cancer 2009;10:99-105.

29 Kelly RJ, Gulley JL, Giaccone G: Targeting the immune system in non-small-cell lung cancer: Bridging the gap between promising concept and therapeutic reality. Clin Lung Cancer 2010;11:228-237. 


\section{Cellular Physiology Cell Physiol Biochem 2016;38:1303-1318 \begin{tabular}{l|l|l}
\hline DOI: 10.1159/000443125 & $\begin{array}{l}\text { C } 2016 \text { The Author(s). Published by S. Karger AG, Basel } \\
\text { www.karger.com/cpb }\end{array}$ \\
\hline
\end{tabular}

30 Darani HY, Shirzad H, Mansoori F, Zabardast N, Mahmoodzadeh M: Effects of toxoplasma gondii and toxocara canis antigens on wehi-164 fibrosarcoma growth in a mouse model. Korean J Parasitol 2009;47:175-177.

31 Chen L, He Z, Qin L, Li Q Shi X, Zhao S, Zhong N, Chen X: Antitumor effect of malaria parasite infection in a murine lewis lung cancer model through induction of innate and adaptive immunity. PLoS One 2011;6:e24407.

32 Bufford JD, Gern JE: The hygiene hypothesis revisited. Immunol Allergy Clin North Am 2005;25:247-262.

33 Strachan DP: Hay fever, hygiene, and household size. BMJ 1989;299:1259-1260.

34 Martindale JL, Holbrook NJ: Cellular response to oxidative stress: Signaling for suicide and survival. J Cell Physiol 2002;192:1-15.

35 Forman HJ: Use and abuse of exogenous h2o2 in studies of signal transduction. Free Radic Biol Med 2007;42:926-932.

36 Ullrich SJ, Sakaguchi K, Lees-Miller SP, Fiscella M, Mercer WE, Anderson CW, Appella E: Phosphorylation at ser-15 and ser-392 in mutant p53 molecules from human tumors is altered compared to wild-type p53. Proc Natl Acad Sci USA 1993;90:5954-5958.

37 Lohrum M, Scheidtmann KH: Differential effects of phosphorylation of rat p53 on transactivation of promoters derived from different p53 responsive genes. Oncogene 1996;13:2527-2539.

38 Kohn KW: Molecular interaction map of the mammalian cell cycle control and DNA repair systems. Mol Biol Cell 1999;10:2703-2734.

39 Hao M, Lowy AM, Kapoor M, Deffie A, Liu G, Lozano G: Mutation of phosphoserine 389 affects p53 function in vivo. J Biol Chem 1996;271:29380-29385.

40 Oda K, Arakawa H, Tanaka T, Matsuda K, Tanikawa C, Mori T, Nishimori H, Tamai K, Tokino T, Nakamura Y, Taya Y: P53aip1, a potential mediator of p53-dependent apoptosis, and its regulation by ser-46phosphorylated p53. Cell 2000;102:849-862.

41 Stambolsky P, Weisz L, Shats I, Klein Y, Goldfinger N, Oren M, Rotter V: Regulation of aif expression by p53. Cell Death Differ 2006;13:2140-2149.

42 Sablina AA, Budanov AV, Ilyinskaya GV, Agapova LS, Kravchenko JE, Chumakov PM: The antioxidant function of the p53 tumor suppressor. Nat Med 2005;11:1306-1313.

43 Yao N, Li YJ, Zhang DM, Liu DL, Tang MK, Yiu A, Li Y, Chen WM, Lan P, Yao Z, Chen ZS, Ye WC: B4g2 induces mitochondrial apoptosis by the ros-mediated opening of ca(2+)-dependent permeability transition pores. Cell Physiol Biochem 2015;37:838-852.

44 Lou G, Liu Y, Wu S, Xue J, Yang F, Fu H, Zheng M, Chen Z: The p53/mir-34a/sirt1 positive feedback loop in quercetin-induced apoptosis. Cell Physiol Biochem 2015;35:2192-2202.

45 Yang H, Xiong J, Luo W, Yang J, Xi T: 8-methoxypsoralen induces intrinsic apoptosis in hepg2 cells: Involvement of reactive oxygen species generation and erk1/2 pathway inhibition. Cell Physiol Biochem 2015;37:361-374.

46 Hung RS: Effectos citopatogenicos en cellulas ma-104 producidos por lisados de trypanosoma cruzi. Ada Cient Venez 1972;23:86-88.

47 Tavares J, Ouaissi M, Ouaissi A, Cordeiro-da-Silva A: Characterization of the anti-leishmania effect induced by cisplatin, an anticancer drug. Acta Trop 2007;103:133-141.

48 Leikina MI: On the assay for anticancer activity of cruzin in human malignant cell culture, protivorakovyi antibiotik krutsin (anticancer antibiotic cruzin). Mosk Gos Univ 1968:267-271.

49 Gershanovich VN, Zuev VA, Bunina NN, Kuznetsova NV, Kats GI: [the chemical nature and the mechanism of action of a succinic oxidase reaction inhibitor from trypanosoma cruzi]. Biokhimiia 1962;27:252-259.

50 Gershanovich VN, Kuznetsova NV, Bunina NN: [succinic dehydrogenase reaction inhibitor from trypanosoma cruzi]. Biokhimiia 1961;26:323-331.

51 Trufanov AV, Palkina NA: [effect of the antibiotic cruzin on succinic dehydrogenase and cytochrome oxidase of tumor tissue]. Biokhimiia 1960;25:787-789.

52 Latif F, Tory K, Gnarra J, Yao M, Duh FM, Orcutt ML, Stackhouse T, Kuzmin I, Modi W, Geil L, et al.: Identification of the von hippel-lindau disease tumor suppressor gene. Science 1993;260:1317-1320.

53 Chakrabarty AM: Microbial pathogenicity: A new approach to drug development. Adv Exp Med Biol 2014;808:41-49. 